This item was submitted to Loughborough's Research Repository by the author.

Items in Figshare are protected by copyright, with all rights reserved, unless otherwise indicated.

\title{
Room temperature surface passivation of silicon for screen printed c-Si solar cells by HiTUS reactive sputter deposition
}

PLEASE CITE THE PUBLISHED VERSION

http://dx.doi.org/doi:10.1016/j.apsusc.2014.01.207

PUBLISHER

(C) Elsevier

VERSION

AM (Accepted Manuscript)

LICENCE

CC BY-NC-ND 4.0

\section{REPOSITORY RECORD}

Claudio, Gianfranco, Piotr M. Kaminski, Kevin Bass, and Michael Walls. 2019. "Room Temperature Surface Passivation of Silicon for Screen Printed C-si Solar Cells by Hitus Reactive Sputter Deposition”. figshare. https://hdl.handle.net/2134/14147. 
This item was submitted to Loughborough's Institutional Repository (https://dspace.lboro.ac.uk/) by the author and is made available under the following Creative Commons Licence conditions.

\section{(c) creative}

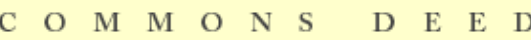

Attribution-NonCommercial-NoDerivs 2.5

You are free:

- to copy, distribute, display, and perform the work

Under the following conditions:

Attribution. You must attribute the work in the manner specified b the author or licensor.

Noncommercial. You may not use this work for commercial purposes.

No Derivative Works. You may not alter, transform, or build upon this work.

- For any reuse or distribution, you must make clear to others the license terms of this work.

- Any of these conditions can be waived if you get permission from the copyright holder.

Your fair use and other rights are in no way affected by the above.

This is a human-readable summary of the Leqal Code (the full license).

\section{Disclaimer 만}

For the full text of this licence, please go to: http://creativecommons.org/licenses/by-nc-nd/2.5/ 


\section{Accepted Manuscript}

Title: Room Temperature Surface Passivation of Silicon for Screen Printed c-Si Solar Cells by HiTUS Reactive Sputter Deposition

Author: P.M. Kaminski K. Bass G. Claudio J.M. Walls

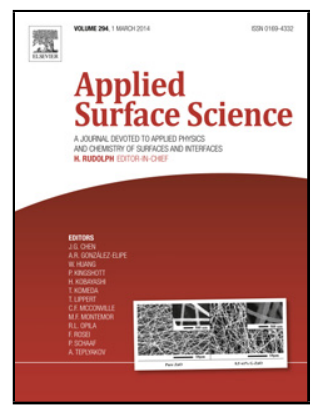

PII:

S0169-4332(14)00273-6

DOI: http://dx.doi.org/doi:10.1016/j.apsusc.2014.01.207

Reference: APSUSC 27215

To appear in:

APSUSC

Received date:

30-10-2013

Revised date:

27-1-2014

Accepted date:

$31-1-2014$

Please cite this article as: P.M. KaminskiK. BassG. ClaudioJ.M. Walls Room Temperature Surface Passivation of Silicon for Screen Printed c-Si Solar Cells by HiTUS Reactive Sputter Deposition (2014), http://dx.doi.org/10.1016/j.apsusc.2014.01.207

This is a PDF file of an unedited manuscript that has been accepted for publication. As a service to our customers we are providing this early version of the manuscript. The manuscript will undergo copyediting, typesetting, and review of the resulting proof before it is published in its final form. Please note that during the production process errors may be discovered which could affect the content, and all legal disclaimers that apply to the journal pertain. 


\title{
Room Temperature Surface Passivation of Silicon for Screen Printed c-Si Solar Cells by HiTUS Reactive Sputter Deposition
}

\author{
P.M.Kaminski ${ }^{1}{ }^{*}$, K.Bass $^{1}$, G.Claudio ${ }^{1}$, J.M.Walls ${ }^{1}$ \\ ${ }^{1}$ Centre for Renewable Energy Systems Technology, (CREST), School of Electronic, \\ Electrical and Systems Engineering, Loughborough University, Leicestershire, LE11 3TU, \\ UK \\ *corresponding author: P.M.Kaminski@lboro.ac.uk
}

\begin{abstract}
The dielectric coatings used on silicon solar cells serve a dual purpose: a surface passivation layer and as an antireflection coating. Silicon nitride films were deposited by sputtering, using a HiTUS technology, on crystalline silicon wafers. Films were deposited without substrate heating, which simplifies the deposition process, from a polycrystalline silicon target in a mixed ambient of Argon, Nitrogen and Hydrogen gasses. After the deposition, the minority carrier lifetime, refractive index and deposition rate were measured. Photo conductance decay measurements show that the minority carrier lifetime increased up to $26 \mu$ s on a $40 \Omega / \square$ doped $1 \Omega$-cm p-type $<100>\mathrm{Cz}$-Si pseudo square wafer (compared to $1 \mu$ s measured for bare wafer) and up to $984 \mu$ s for a double-side polished $3 \Omega$-cm Cz-Si wafer (from $\sim 70 \mu \mathrm{s}$ measured for uncoated wafer). Spectroscopic ellipsometry measurements showed that the refractive index of the deposited films was 2.05 at $\lambda=632.8 \mathrm{~nm}$; deposition rate was measured at $22.4 \mathrm{~nm} / \mathrm{min}$. The films were used to prepare screen-printed c-Si solar cells. The resultant cells showed an efficiency of $15.14 \%$ with silicon nitride films grown without the use of silane or substrate heating.
\end{abstract}

\section{Introduction}

Silicon wafer based technology is the dominant technology for the production of solar panels and accounts for $\sim 88 \%$ of the total market [1]. The preparation of solar cells involves the deposition of an anti-reflective coating (ARC) onto the silicon wafer, which also serves as a passivation layer for the surface of the solar cell. The surface of the solar cell requires electrical passivation to avoid recombination loses through the trapping states present due to dangling bonds introduced by crystalline lattice discontinuity. A typical solution to this is to 
deposit a thin film of amorphous hydrogenated silicon nitride $\left(\mathrm{a}-\mathrm{SiN}_{\mathrm{x}}: \mathrm{H}\right)$, by means of a Chemical Vapour Deposition (CVD) process. Most commonly CVD techniques used include Plasma Enhanced CVD (PECVD) and Low Pressure CVD (LPCVD). In PECVD the layers are deposited by the chemical reaction of Ammonia $\left(\mathrm{NH}_{3}\right)$ and Silane $\left(\mathrm{SiH}_{4}\right)$ at temperatures around $400^{\circ} \mathrm{C}$ [2]. The $\mathrm{SiH}_{4}$ precursor is both pyrophoric and toxic which requires complex and costly safety systems. Sputtering allows the growth of a film without the use of $\mathrm{SiH}_{4}$. Moreover, sputtering allows the deposition of thin films of a-SiN $\mathrm{x}: \mathrm{H}$ without substrate heating.

Silicon nitride is a dielectric material with a band gap of $5.2 \mathrm{eV}$; which allows the transmission of all photons with wavelength longer than $240 \mathrm{~nm}$ to reach the silicon wafer through the film. Silicon nitride has a refractive index tuneable in the range from 1.9 to 2.7. However, the refractive index and the band gap are inversely linked, therefore when one increases the other decreases [3].

PECVD allows fast deposition of $\mathrm{a}-\mathrm{SiN}_{\mathrm{x}}: \mathrm{H}$. For laboratory scale systems deposition rates between $9 \mathrm{~nm} / \mathrm{s}$ [4] and $30 \mathrm{~nm} / \mathrm{sec}$ [5] have been reported, for different system configurations. For industrial scale systems deposition rates in the range of 30 to $120 \mathrm{~nm} / \mathrm{s}$ were reported [6]. Large throughput systems achieve minority carrier lifetime on $\mathrm{Fz}$ polished substrate in the range between $100 \mu \mathrm{s}$ and $400 \mu \mathrm{s}$, and these lifetimes are related to the refractive index of the deposited film. The passivation improves as more silicon is incorporated into the film and the index increases, the numbers reported were for films with $n=1.8$ and $n=2.4$ respectively [6]. However, stoichiometric silicon nitride films were also reported to provide passivation levels better than thermal oxide, $\tau=895 \mu$ s on $1 \Omega$-cm, p-type polished Fz wafer [7]. The drawback of using a Si rich film is a narrower band gap, which leads to a red shift of the absorption edge [6].

The passivation achieved with hydrogen incorporation into the film was explained by two different mechanisms. Firstly, passivation of the dangling bonds, which is proportional to the $\mathrm{H}_{2}$ content in the deposited film. The second mechanism present was a change of the Fermi level in the a-SiN $: \mathrm{H}$ film caused by the introduction of $\mathrm{H}_{2}$, which influences band bending at the a-SiN $\mathrm{x}: \mathrm{H} / \mathrm{Si}$ interface $[8,9]$.

PECVD is the preferred technology for the deposition of the silicon nitride coating for c-Si PV, however there are some drawbacks including: use of hazardous and expensive precursors. These problems could be overcome by replacing PECVD with a sputtering technique. The films are deposited from solid targets, either from silicon nitride or silicon in a reactive gas atmosphere negating the use of silane. Sputtering is also known to deposit highly uniform 
films with a nanometre precision, and it is an easily up-scalable process with a proven track record of excellent results in the glass industry. Sputtering is a very versatile deposition technique; it allows easy adjustment of film properties by changing the power settings and deposition atmosphere. It was shown that the refractive index of sputtered a-SiN $\mathrm{x}: \mathrm{H}$ can be tuned by control of the reactive gas ratio [10], deposition pressure [11,12], substrate temperature [12] and supplied power [10] .

\section{Experimental}

\subsection{Thin film deposition}

HiTUS is a unique sputtering technique developed by Plasma Quest Ltd. HiTUS uses a remote plasma source, which is created remotely in a side-arm, called the Plasma Launch System (PLS). A schematic of the HiTUS tool used in this study is presented in Figure 1. The tool consists of the main deposition chamber and an attached PLS remote plasma source. The PLS consists of a quartz tube and an RF coil which couples power into the system. Apart from the RF source used in the PLS there is an additional RF power supply to bias the target during the deposition. Both power supplies work at $13.64 \mathrm{MHz}$ frequency. The PLS power supply has a power of $3 \mathrm{~kW}$; the target bias power supply is smaller and rated at $1 \mathrm{~kW}$. The system also has two electro-magnets to control the plasma direction. The magnets are powered by two DC power supplies. The first, 'Launch' magnet is used to extend the plasma into the main chamber. The second, 'Steering' magnet is used to guide the plasma beam onto the target. The plasma is created in the PLS and, by means of a magnetic field, directed on to the target. Due to the small ion energy of the plasma $(\sim 10 \mathrm{eV})$ no sputtering happens before the RF bias is applied to the target, this allows control of the plasma independently of the sputtering. The substrate is mounted on a rotating stage behind which a resistive heater is mounted. The system is equipped with mass flow controllers allowing the supply of argon (Ar), nitrogen $\left(\mathrm{N}_{2}\right)$, and hydrogen $\left(\mathrm{H}_{2}\right)$ gases to the chamber. 


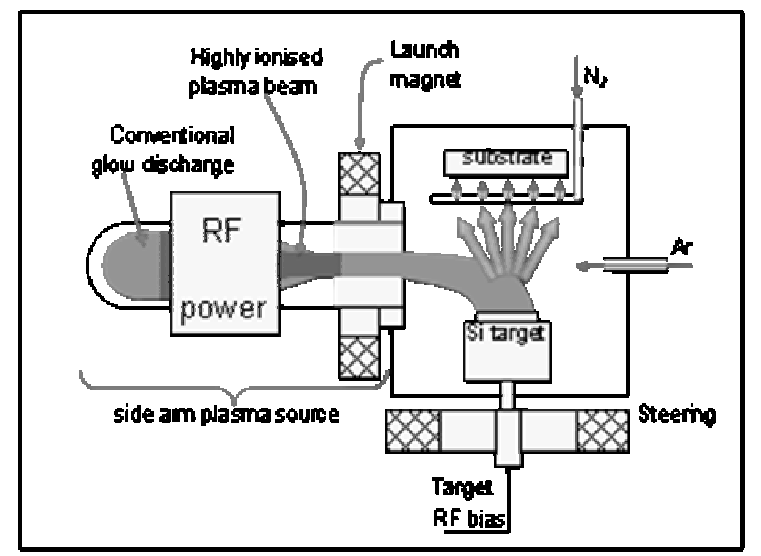

Figure 1 Diagram of the HiTUS sputtering system. The equipment has a unique design with a Plasma Launch System (PLS) in which the plasma is inductively created, away from main chamber.

Passivation tests were made by depositing silicon nitride directly onto both surfaces of a high quality $500 \mu \mathrm{m}$ thick $\mathrm{CZ}$ p-type four inch round silicon wafer with a bulk resistivity of $3 \Omega$-cm, boron doped with a $<100>$ crystalline orientation of the surface.

The a-SiN $\mathrm{x}: \mathrm{H}$ films were also grown on $200 \mu \mathrm{m}$ thick $<100>$ p-type wafer with a bulk resistivity of $1 \Omega-\mathrm{cm}$. Prior to the film deposition the wafers were anisotropically textured to form a random pyramid surface in a solution of $\mathrm{NaOH}$ and IPA in DI water. The wafers were subsequently doped in a diffusion furnace by $\mathrm{POCl}_{3}$ gas in presence of Oxygen. The doping was performed at $900^{\circ} \mathrm{C}$, with a $15 \mathrm{~min}$ deposition time followed by $30 \mathrm{~min}$ drive-in step, resulting in a $40 \Omega / \square$ shallow emitter at the surface. The effective minority carrier lifetime was monitored to control the surface passivation of the silicon wafer; using a WTC-100 lifetime tester.

After the ARC passivation layers had been deposited, front and back contacts were subsequently printed and fired in a four zone IR belt furnace. The schematic of the screen printed solar cell is shown in Figure 2. The cells travelled through the furnace at speeds between 40 and $50 \mathrm{~cm} /$ minute, the heating zones were set to $280^{\circ} \mathrm{C} / 300^{\circ} \mathrm{C} / 400^{\circ} \mathrm{C} / 770^{\circ} \mathrm{C}$. The firing process was conducted in air. 


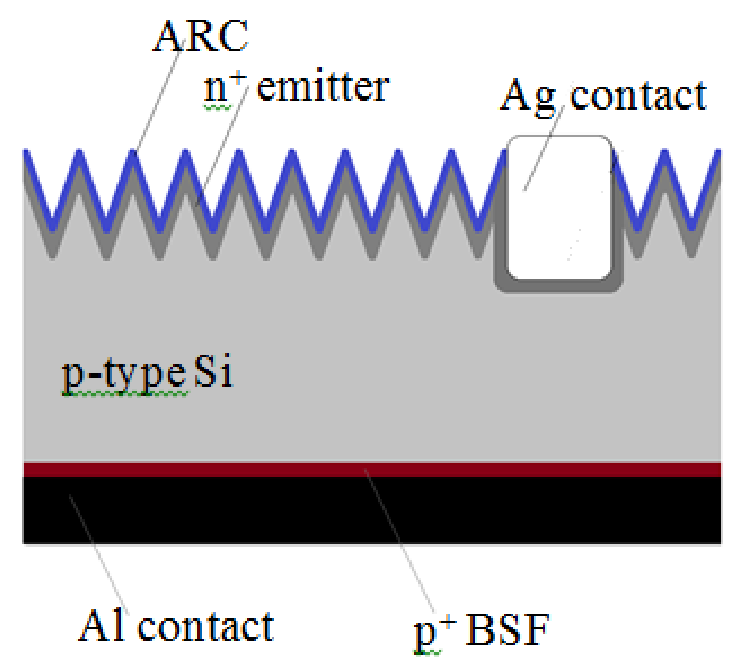

Figure 2 Cross section of a screen printed solar cell.

The ARC/passivation coating was modelled and optimised in Essential Macleod software. Essential Macleod is an optical modelling software package which allows simulation of the optical performance of devices utilising a thin film dielectric layer/multilayer system for light management. The modelling is based on a transfer matrix method [13].

\subsection{Characterisation}

Surface passivation by the deposited $\mathrm{a}-\mathrm{SiN}_{\mathrm{x}}: \mathrm{H}$ films was checked by measurements of an effective minority carrier lifetime $\left(\tau_{\text {eff }}\right)$, which were taken by Sinton Consulting WTC-100 photo-conductance decay measurement system. The minority carrier lifetime was measured for all samples; solar cells additionally were characterised by a Suns Voc measurement after metallisation.

For the double side coated sample the Surface Recombination Velocity (SRV) was calculated using a formula given in Equation 1[14]; assuming that recombination at the surface was limiting the minority carrier lifetime.

$\frac{1}{\tau_{s f f}}=\frac{1}{\tau_{b u l k}}+\frac{2 S R V}{w} \quad$ Equation 1

Where: $\tau_{\text {bulk }}$ - bulk lifetime, $\mathbf{w}$ - wafer thickness

The refractive index and thickness of the deposited films were measured using spectroscopic ellipsometry (Horiba Jobin Yvon UVISEL iHR320FGAS), to assess the optical suitability of the material for the ARC. 
Effectiveness of the ARC was also assessed by spectrophotometer measurements of reflection using Varian UV-Vis 5000. The common approach is to calculate the weighted average reflection (WAR) by the photon flux in the AM1.5G spectrum.

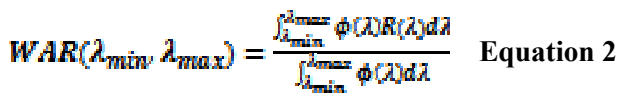

Where: $\lambda$ is a wavelength, $\Phi(\lambda)$ is the photon flux at $\lambda$ in AM1.5g and $\mathbf{R}(\lambda)$ is a reflection coefficient at given wavelength.

The $70 \mathrm{~nm}$ thick layer ARC with refractive index of $\mathrm{n}=2.0$ (at $\lambda=632.8 \mathrm{~nm}$ ) allows the WAR(300nm, $1200 \mathrm{~nm})$ to be brought down to $6.2 \%$ [3], from $11.6 \%$ measured for silicon wafer with random pyramid surface texture. The maximum current density of a solar cell based on material with $\mathrm{E}_{\mathrm{g}}=1.12 \mathrm{eV}$ is $\sim 46 \mathrm{~mA} / \mathrm{cm}^{2}$ at the $\mathrm{AM} 1.5 \mathrm{~g}$ illumination, the optical losses of $6.2 \%$ correspond to $3 \mathrm{~mA} / \mathrm{cm}^{2}$.

The efficiency of prepared solar cells was measured using PASAN SUNSIM $3 b$ class AAA solar simulator.

The external quantum efficiency (EQE) of the solar cells was measured using an in-house built EQE system, combined with spectrophotometer reflection measurements the internal quantum efficiency (IQE) was calculated.

\section{Results}

\subsection{Surface Passivation}

Silicon nitride films were deposited in HiTUS using a polycrystalline silicon target at a PLS power of $2.85 \mathrm{~kW}$ and a target bias of $900 \mathrm{~W}$. The gas flows were set to $50 \mathrm{sccm} \mathrm{Ar}, 7 \mathrm{sccm} \mathrm{N} \mathrm{N}_{2}$ and $3 \mathrm{sccm}$ of $\mathrm{H}_{2}$ during the deposition, corresponding to partial pressures of $68 \mathrm{mPa}, 48 \mathrm{mPa}$ and $3.5 \mathrm{mPa}$ respectively. The films were deposited at a deposition rate of $22.4 \mathrm{~nm} / \mathrm{min}$. The lifetime tests on doped wafers showed a minority carrier lifetime of $26 \mu$ s (compared to $\sim 1 \mu \mathrm{s}$ for bare wafer). Tests on a high quality $\mathrm{Cz}-\mathrm{Si}$ wafer showed a minority carrier lifetime of $984 \mu \mathrm{s}$ at $1 \times 10^{15} \mathrm{~cm}^{-3}$ minority carrier density (Figure 3 ); this minority carrier lifetime corresponds to Surface Recombination Velocity (SRV) of $25 \mathrm{~cm} / \mathrm{s}$. 


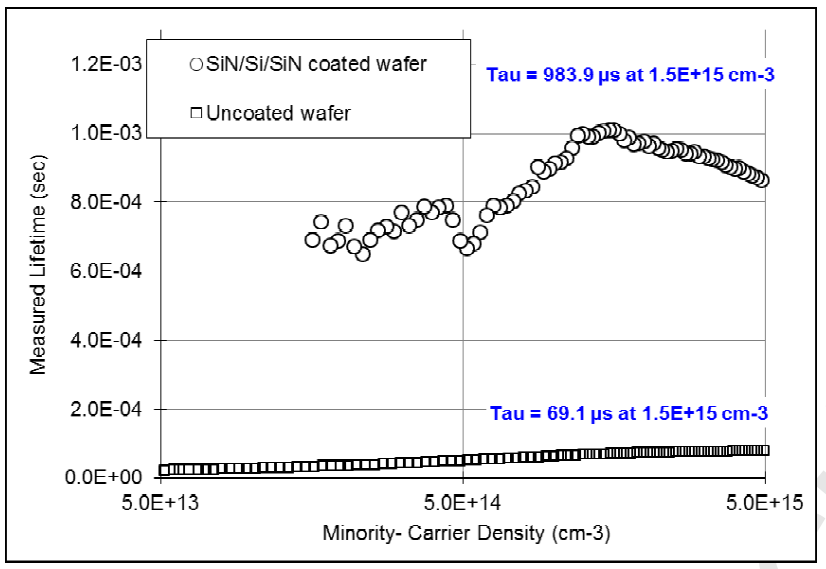

Figure 3 Effective minority carrier lifetime measured for the double side coated high quality CZ-Si wafer, and uncoated wafer.

\subsection{Optical properties}

The refractive index of the deposited film was 2.05 at $\lambda=632.8 \mathrm{~nm}$. Full dispersion of the refractive index measured with spectroscopic ellipsometer is shown in Figure 4.

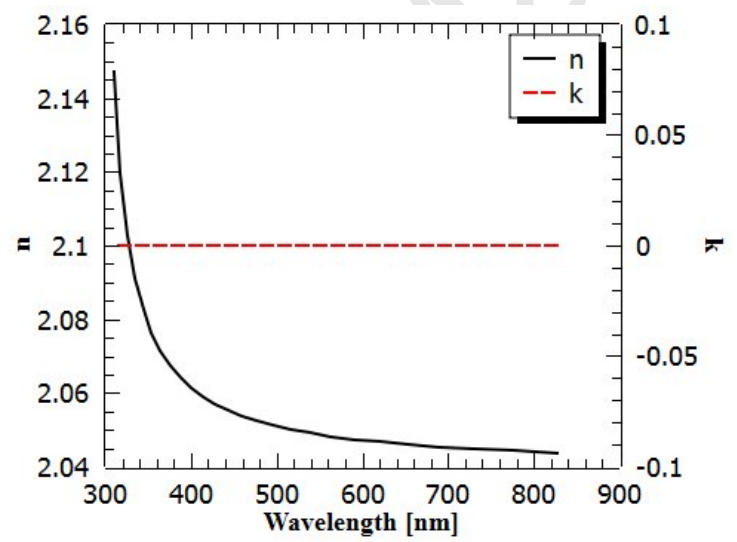

Figure 4 Refractive index dispersion of the deposited silicon nitride film

The refractive index dispersion was used to calculate the optimal thickness of the coating. Figure 5 shows modelled transmission into the silicon solar cells coated with an ARC with thickness between $10 \mathrm{~nm}$ and $110 \mathrm{~nm}$. 


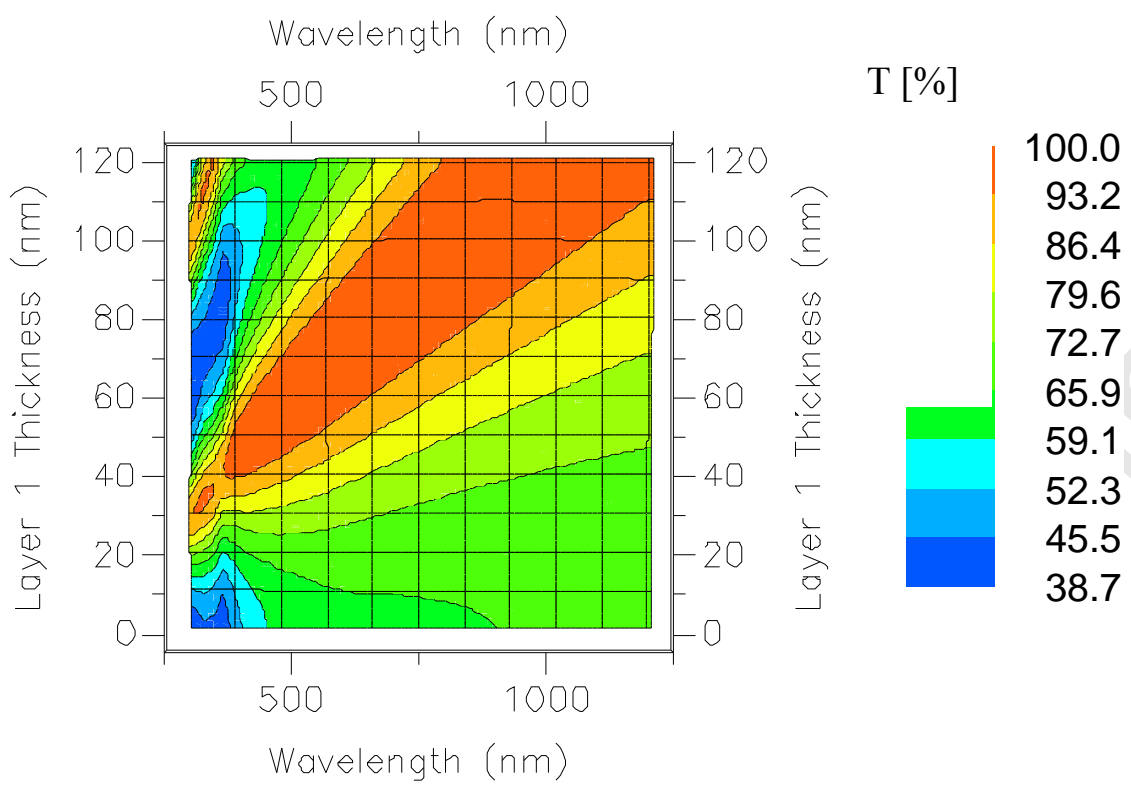

Figure 5 Spectra of light transmission into the silicon wafer for different thickness of a single layer a-SiN ${ }_{x}: \mathrm{H}$ coating. Results produced by a model in Essential Macleod software.

The modelled data was analysed, for each spectrum obtained for individual thicknesses maximum obtainable short circuit current was calculated. The short circuit current was calculated assuming a cell with 100\% IQE in the considered spectral range. Figure 6 shows how much current can be obtained by a $1 \mathrm{~cm}^{2}$ cell with different thickness of the ARC; the analysis was performed for a laboratory type cell without encapsulation. The maximum current was found for a $75 \mathrm{~nm}$ thick ARC, with a value of $42.2 \mathrm{~mA} / \mathrm{cm}^{2}$. The maximum theoretical current obtainable for this considered spectral range is $46.07 \mathrm{~mA} / \mathrm{cm}^{2}$; in this case the $3.87 \mathrm{~mA} / \mathrm{cm}^{2}$ would be lost due to reflection from the front surface of the cell.

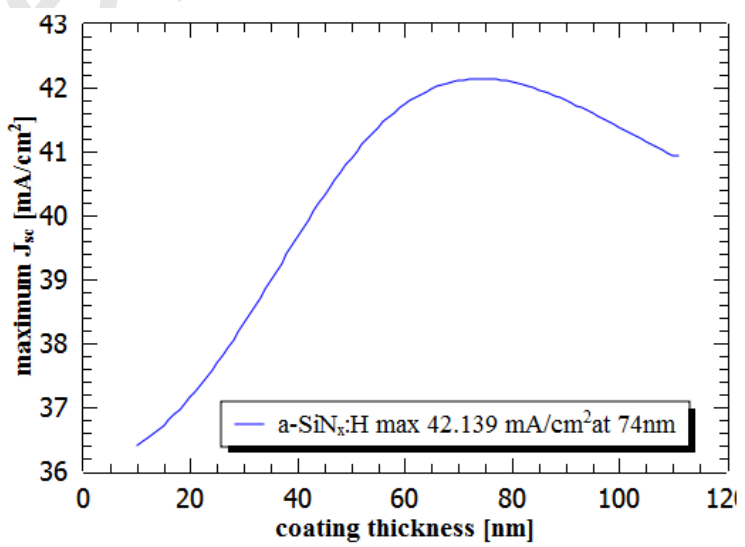

Figure 6 Maximum short circuit obtainable by c-Si solar cell with a different thickness of the ARC prepared using HiTUS deposited a-SiN $\mathrm{N}_{\mathrm{x}}: \mathrm{H}$. The simulation did not account for reflection losses due to metallisation. 


\subsection{Screen printed solar Cell}

\subsubsection{Efficiency}

The films obtained were used for preparation of screen printed solar cells. The minority carrier lifetime after the ARC deposition was measured to be $26.2 \mu \mathrm{s}$ at $1 \times 10^{15} \mathrm{~cm}^{-3}$. Results of a standard test condition of the cell's efficiency are summarised in Table 1; the minority carrier lifetime was measured using SunsVoc measurement.

Table 1 Solar cell efficiency $(3 \mathrm{~cm} \times 3 \mathrm{~cm}$ cell area)

\begin{tabular}{lllllll}
\hline $\begin{array}{l}\text { Serial } \\
\text { Number }\end{array}$ & ARC & $\eta[\%]$ & $\begin{array}{l}\mathrm{Jsc} \\
{\left[\mathrm{mA} / \mathrm{cm}^{2}\right]}\end{array}$ & $\begin{array}{l}\text { Voc } \\
{[\mathrm{V}]}\end{array}$ & FF [\%] & $\boldsymbol{\tau}[\boldsymbol{\mu s}] \mathbf{1} \mathbf{e 1 5} \mathbf{c m}^{-\mathbf{3}}$ \\
\hline $\mathrm{s} 41$ & $\mathrm{a}-\mathrm{SiN}_{\mathrm{x}}: \mathrm{H}$ & 15.14 & 31.86 & 0.610 & 0.78 & $\mathbf{3 4 . 7}$ \\
\hline
\end{tabular}

\subsubsection{Reflection characteristics}

Reflection of the light from the front surface of the completed solar cells was measured using a spectrophotometer. The reflection spectrum measured is plotted in Figure 7; the results showed that the weighted average reflection for the prepared solar cell was $10.03 \%$; this corresponds to $4.62 \mathrm{~mA} / \mathrm{cm}^{2}$ in short circuit current at $100 \%$ Internal Quantum Efficiency (IQE). The current obtainable was $0.75 \mathrm{~mA} / \mathrm{cm}^{2}$ lower than predicted by the optical modelling in Essential Macleod due to reflection loses induced by the front metallisation.

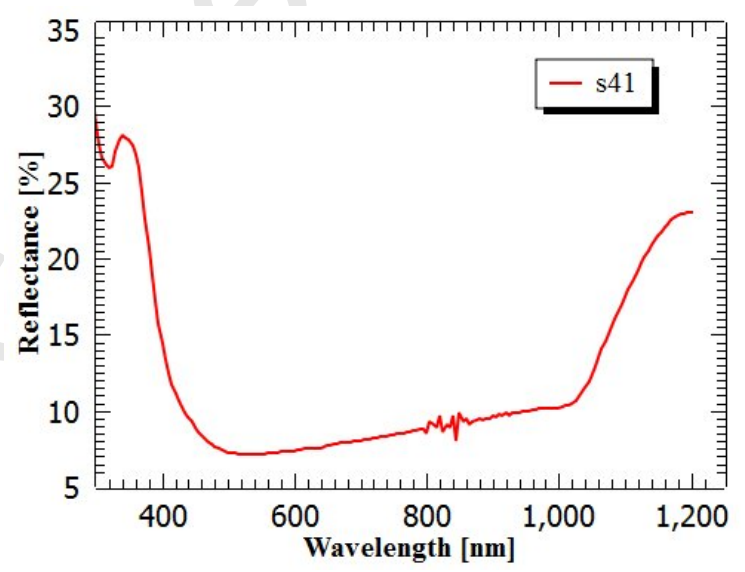

Figure 7 Reflection spectra measured for the prepared solar cell.

\subsubsection{Quantum Efficiency}

Figure 8 shows External and Internal Quantum Efficiencies characteristics measured for the prepared solar cell. 


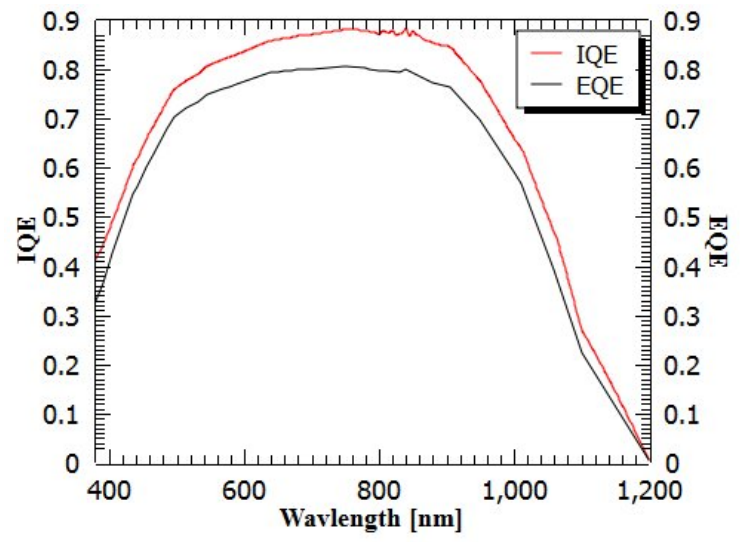

Figure $8 \mathrm{EQE}$ and IQE of the solar cell measured between $400 \mathrm{~nm}$ and $1200 \mathrm{~nm}$.

Figure 9 shows analysis of current generation in the prepared solar cell. The black line shows the maximum current which could be generated by a silicon solar cell at AM1.5g illumination (assumed 100\% EQE). The blue area shows the current generation across the spectrum by a device with an ARC utilising HiTUS deposited coating and a 100\% internal quantum efficiency. The red area shows the current actually generated in the prepared solar cell; the difference between the blue and the red area corresponds to the recombination losses in the solar cell.

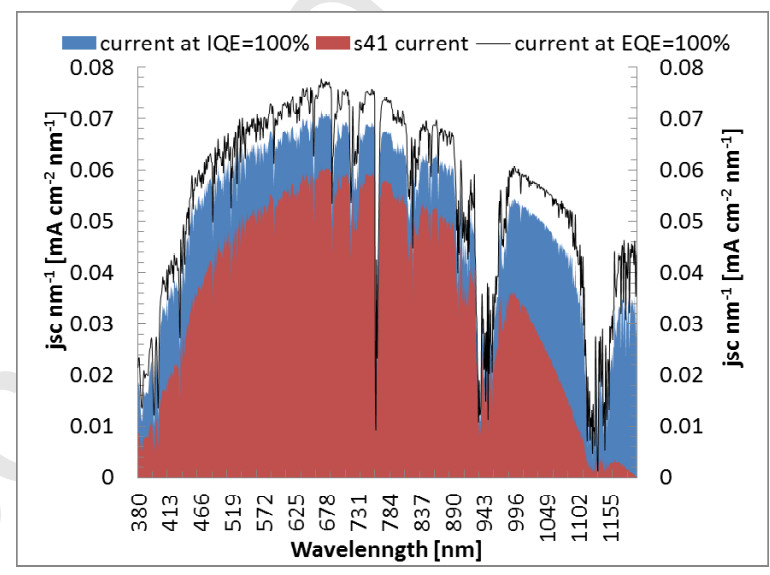

Figure 9 Current generation in the solar cell prepared at different light wavelengths (red area), blue area shows current gain which can be obtained by eliminating recombination losses, the black line shows maximum current obtainable across the spectrum.

\section{Summary}

Silicon nitride films were deposited by sputtering using a HiTUS technique; the films were grown without using silane as a precursor and the substrates were not heated during the growth. 
The deposited a-SiN $\mathrm{x}: \mathrm{H}$ films delivered an effective minority carrier lifetime of $26 \mu$ s on a doped wafer and $985 \mu \mathrm{s}$ on high quality wafers; which corresponds to an implied $\mathrm{V}_{\text {oc }}$ of $\sim 680 \mathrm{mV}$ and SRV of $25 \mathrm{~cm} / \mathrm{s}$. These results are comparable with those reported for a PECVD deposited silicon nitride film: [15]-1ms minority carrier lifetime and SRV of $4-20 \mathrm{~cm} / \mathrm{s}$, [16] 10 to $60 \mu$ s minority carrier lifetime on PV quality wafers).

The deposited a-SiN $: H$ films showed refractive index of 2.05 at $\lambda=632.8 \mathrm{~nm}$ and no absorption in the visible spectrum range.

The modelling showed that the WAR can be reduced down to $6.9 \%$ with the HiTUS deposited $\mathrm{a}-\mathrm{SiN}_{\mathrm{x}}: \mathrm{H}$, from $11.6 \%$ measured for an uncoated silicon surface with random pyramid texture.

Deposition rates up to $22.4 \mathrm{~nm} / \mathrm{min}$ were obtained for the a-SiN$: \mathrm{H}$. These numbers are high in comparison to values reported for laboratory scale sputtering tools $(8 \mathrm{~nm} / \mathrm{min}$ to $10 \mathrm{~nm} / \mathrm{min})$ $[11,12]$, and similar to ones reported for PECVD laboratory systems $14 \mathrm{~nm} / \mathrm{min}$ [4] to $30 \mathrm{~nm} / \mathrm{min}$ [17], and can be improved further by reducing the distance between the target and the substrate.

The deposited layers meet all the criteria for the ARC in silicon solar cells. The coatings were deposited without the use of silane and were also deposited without the use of substrate heating. This makes the technology very attractive, for high volume processing required, for solar cell fabrication.

Screen printed solar cells were prepared using an ARC/passivation coatings prepared in HiTUS. The WAR measured for the prepared cells was $10 \%$. The WAR was higher compared to the modelled values due to losses caused by reflection from the metal contact grid of the cell.

Efficiency of $15.14 \%$ was achieved by using an ARC/passivation layer deposited without substrate heating during the film deposition. This is a great advantage over other technologies which require substrate heating.

\section{References}

[1] IEA-PVPS, TRENDS 2013 in Photovoltaics Appliations, 2013.

[2] T. Lauinger, J. Schmidt, A.G. Aberle, R. Hezel, Record low surface recombination velocities on $1 \Omega \mathrm{cm}$ p-silicon using remote plasma silicon nitride passivation, Appl. Phys. A Mater. Sci. Process. 68 (1996) 1231-4. 
[3] S. Duttagupta, F. Ma, B. Hoex, T. Mueller, A.G. Aberle, Optimised Antireflection Coatings using Silicon Nitride on Textured Silicon Surfaces based on Measurements and Multidimensional Modelling, Energy Procedia. 15 (2012) 78-83.

[4] J. Yoo, J. So, G. Yu, J. Yi, Study on hydrogenated silicon nitride for application of high efficiency crystalline silicon solar cells, Sol. Energy Mater. Sol. Cells. 95 (2011) $7-10$.

[5] A. Elamrani, I. Menous, L. Mahiou, R. Tadjine, A. Touati, A. Lefgoum, Silicon nitride film for solar cells, Renew. Energy. 33 (2008) 2289-2293.

[6] W. Soppe, H. Rieffe, A. Weeber, Bulk and surface passivation of silicon solar cells accomplished by silicon nitride deposited on industrial scale by microwave PECVD, Prog. Photovoltaics Res. Appl. 13 (2005) 551-569.

[7] J. Schmidt, M. Kerr, Highest-quality surface passivation of low-resistivity p-type silicon using stoichiometric PECVD silicon nitride, Sol. Energy Mater. Sol. Cells. 65 (2001) 585-591.

[8] M. Vetter, Surface passivation of silicon by rf magnetron-sputtered silicon nitride films, Thin Solid Films. 337 (1999) 118-122.

[9] M. Vetter, Properties of amorphous Si-rich silicon nitride prepared by RF-magnetron sputtering, Mater. Sci. Eng. B. 71 (2000) 321-326.

[10] M. Vila, C. Prieto, J. Garcia-Lopez, M. Respaldiz.a, Influence of the target and working gas on the composition of silicon nitride thin films prepared by reactive RFsputtering, Nucl. Instruments Methods Phys. Res. Sect. B Beam Interact. with Mater. Atoms. 211 (2003) 199-205.

[11] W. Li, D.R. McKenzie, W.D. McFall, Q. Zhang, Effect of sputtering-gas pressure on properties of silicon nitride films produced by helicon plasma sputtering, Thin Solid Films. 384 (2001) 46-52.

[12] K. Choi, K. Kim, Antireflection coating of a $\mathrm{SiO} / \mathrm{SiN}$ double layer on silicon fabricated by magnetron sputtering, J. Ceram. Process. Res. 11 (2010) 341-343.

[13] A. Macleod, C. Clark, Optical Coating Design with the Essential Macleod, Thin Film Center Inc Tucson, 2012.

[14] M. Hofmann, S. Janz, C. Schmidt, S. Kambor, D. Suwito, N. Kohn, et al., Recent developments in rear-surface passivation at Fraunhofer ISE, Sol. Energy Mater. Sol. Cells. 93 (2009) 1074-1078.

[15] J. Schmidt, T. Lauinger, A. Aberle, R. Hezel, Record low surface recombination velocities on low-resistivity silicon solar cell substrates, in: 25th IEEE PVSEC, IEEE, 1996: pp. 413-416. 
[16] U. Coscia, G. Ambrosone, P. Rava, P. Rivolo, F. Ferrazza, L. Serenelli, et al., SiNx/a$\mathrm{SiCx}: \mathrm{H}$ passivation layers for p-and n-type crystalline silicon wafers, Thin Solid Films. 516 (2008) 1569-1573.

[17] H. Kang, A. Ebong, B. Rounsaville, A. Rohatgi, J. Hong, Silane-free PECVD silicon carbon nitride ( $\mathrm{SiCxN}$ y ) passivation and anti-reflection coatings for high efficiency silicon solar cells, in: Proc. 34th IEEE PVSC, 2009: pp. 1724-1726. 


\section{Highlights}

!! Room temperature silicon surface passivation

!! Silane free surface passivation

!! HiTUS remote plasma sputtering for crystalline silicon solar cells 